\title{
Dengue Virus Type 3 Isolation from Aedes aegypti in the Municipality of Nova Iguaçu, State of Rio de Janeiro
}

\section{Ricardo Lourenço-de-O liveira/ ${ }^{+}$, Nildimar A Honório, Márcia G Castro, Hermann G Schatzmayr*, Marize P Miagostovich*, João CR Alves, Wellington C Silva**, Paulo J Leite**, Rita MR Nogueira*} Laboratório de Transmissores de Hematozoários *Laboratório de Flavivírus, Instituto Oswaldo Cruz-Fiocruz, Av. Brasil 4365 ,
21045-900 Rio de Janeiro, RJ, Brasil **Fundação Nacional de Saúde, Nova Iguaçu, RJ, Brasil

In a prospective field study conducted from July 2000 to June 2001, adult Aedes aegypti and Ae. albopictus mosquitoes were caught from the municipality of Nova Iguaçu, State of Rio de Janeiro, Brazil. Virus isolation in Ae. albopictus clone C6/36 cell line and a semi-nested reverse transcription-polymerase chain reaction detected only dengue virus type 3 in three pools of Ae. aegypti, despite the co-circulation of DEN-1, DEN-2 and DEN-3 serotypes in that area. No viruses were detected in Ae. albopictus mosquitoes. This virological surveillance consists in a sentinel system alerting for dengue outbreaks.

Key words: dengue - Aedes aegypti - Aedes albopictus - reverse transcription-polymerase chain reaction - virus isolation Rio de Janeiro - Brazil

Dengue fever is an acute, mosquito-transmitted viral disease caused by any of four virus serotypes (DEN-1, DEN-2, DEN-3 and DEN-4). Nowadays dengue is the most important human disease caused by arbovirus in the world. Its incidence has increased in tropical areas where the main vector Aedes aegypti (Linnaeus) has spread due to unplanned urbanization and lack of effective control (Gubler \& Clark 1996).

In the last 16 years in Brazil an increase in the frequency of epidemics and the geographic expansion of both the mosquito vector and the viruses resulted in the co-circulation of DEN-1 and DEN-2 viruses in 25 out of 27 Brazilian states (Nogueira et al. 1999, Funasa 2001).

In the municipality of Nova Iguaçu, located in the Metropolitan Region of the State of Rio de Janeiro, dengue cases have been reported since DEN-1 virus was isolated for the first time in the State (Schatzmayr et al. 1986, Miagostovich et al. 1993). By the end of December 2000, DEN-3 virus was first isolated from an autochthonous case of dengue fever (Nogueira et al. 2001) when the house infestation levels of Ae. aegypti and Ae. albopictus were $8.1 \%$ and $4.5 \%$, respectively (WC Silva, pers. commun.). Braga et al. (2000) observed that local samples of Ae. aegypti presented $58 \%$ of resistance to temephos.

The high dengue viruses activity in Nova Iguaçu stimulated a series of field studies aiming to elucidate several aspects of dengue vectors' biology started in 1997 (Honório 1999, Honório \& Lourenço-de-Oliveira 2001). Concomitantly with this field work, a project of virologi-

This work was supported by CNPq and US National Institute of Health grant AI-47793. RLO, RMRN, MPM and HGS were supported by a fellowship from CNPq.

${ }^{+}$Corresponding author. Fax: +55-21-2573.4468. E-mail: lourenco@ioc.fiocruz.br

Received 19 December 2001

Accepted 12 March 2002 cal surveillance has been carried out for the detection of dengue virus from field collected Ae. aegypti and Ae. albopictus (Skuse). From July 2000 to June 2001 adult mosquitoes were caught in 35 districts of that municipality. The captures were performed twice a week, alternately in the morning and in the afternoon, with manual and battery backpack aspirators and with nets, both indoors and in the yards and gardens, close to the dwellings. Mosquitoes were captured while flying, seeking for blood or hiding in resting places. Mosquitoes were identified to species, pooled according to sex, date, district and stored in liquid $\mathrm{N}_{2}$ at the same day of collection.

From a total of 2,164 mosquitoes, 503 Ae. aegypti (352 females +151 males) and 80 Ae. albopictus $(58+22)$ were pooled (9-17 mosquitoes/pool) and processed for virus isolation. Briefly, mosquito pools were grounded in $1 \mathrm{ml}$ of Leibovitz L-15 (Gibco BRL, Life Technologies) tissue culture medium and centrifuged for $15 \mathrm{~min}$ at 6,000 rpm. After treatment with penicilin-streptomicin - 10,000 units - (Gibco BRL, Life Technologies) $50 \mu \mathrm{l}$ of the supernatants were inoculated into the monolayer of Ae. albopictus clone C6/ 36 cell line (Igarashi 1978) supplemented with $2 \%$ fetal bovine sera (Gibco BRL, Life Technologies), $1 \%$ non-essential amino-acids (Gibco BRL, Life Technologies) and 10\% tryptose phosphate broth (Gibco BRL, Life Technologies). Culture tubes were kept at $28^{\circ} \mathrm{C}$ and daily observed up to 10 days. Immunofluorescence assays with serotype specific monoclonal antibodies were carried out to detect and subtype dengue virus (Gubler et al. 1984).

Only DEN-3 virus was isolated from three pools of Ae. aegypti containing nine female mosquitoes each. All positive pools were confirmed by reverse transcriptase polymerase chain reaction (RT-PCR) performed according to Lanciotti et al. (1992). This happened despite the inhibitory factors expected when RT-PCR is applied to mosquito pools. No dengue virus was detected from $A e$. albopictus. Despite of the co-circulation of DEN-1, DEN- 
2 and DEN-3 in Nova Iguaçu, only DEN-3 was isolated from mosquitoes. This was probably because mosquitoes were collected essentially in or close to houses reported to have human dengue cases, several of which latter confirmed to be due to DEN-3.

The positive mosquitoes were collected in the districts of Santa Eugênia, Califórnia and Morro Agudo on April 23rd, April 24th, May 28th respectively. Human cases due to DEN-3 virus were confirmed in the two last districts with onset of symptoms on March 3rd and April 27th, being Califórnia the district where the first DEN-3 virus was first isolated from an autochthonous case in Brazil (Nogueira et al. 2001). In 1998 DEN-3 virus had been isolated from an imported dengue case in São Paulo and no more cases were reported afterwards (Rocco et al. 2001). Nevertheless, the isolation of DEN-3 virus in female of Ae. aegypti together with the increasing number of DEN3 laboratory diagnosed cases (91 by October 2001) confirmed the transmission of this serotype in the State of Rio de Janeiro.

Virological and entomological surveillances by detecting dengue infected mosquitoes in the field have been useful as an early warning monitoring system for dengue outbreaks in endemic areas and for the detection of new virus serotype invasion (Chow et al. 1998, Kow et al. 2001). Although DEN-3 virus has been detected in humans from Nova Iguaçu since December 2000, all mosquitoes collected and examined from July 2000 to March 2001 (287 Ae. aegypti and $78 \mathrm{Ae}$. albopictus) were negative. The three positive pools for DEN-3 were composed by mosquitoes caught in April and May 2001, just after the rainy season in the area. If we take into account that the local human population was susceptible to DEN-3 and that a female of both Ae. aegypti and Ae. albopictus may fly at least $800 \mathrm{~m}$ in 6 days in that area (Honório 1999), a rapid spreading of the virus was expected. However, it seems that, even if DEN-3 occurred in the area before December 2000 , its transmission would became important only by the end of the rainy season (Jan-Mar) of 2001, when the local frequency of both mosquito species has the annual peak (Honório \& Lourenço-de- Oliveira 2001). Indeed, after virus isolation from mosquitoes, the number of human cases by DEN-3 has slowly increased during the dry season of 2001 in Nova Iguaçu. But in the following rainy season, this virus has quickly spread in the State of Rio de Janeiro and lead to a severe outbreak of dengue fever and dengue hemorrhagic fever in 2002. These data emphasize the virological and entomological surveillances as sentinel systems alerting for dengue outbreaks.

This is the first report of DEN-3 virus isolation from pools of Ae. aegypti in the country. In 1986 DEN-1 was also isolated from three pools of Ae. aegypti mosquitoes collected in the same municipality of Nova Iguaçu (Nogueira et al. 1988). Other dengue virus serotypes have already been isolated from Ae. aegypti in other states of Brazil (Degallier et al. 1996).

The molecular characterization of the DEN-3 virus from Nova Iguaçu showed that it belongs to the same genotype of the DEN-3 strains circulating in American continent (MP Miagostovich, pers. commun.). These data stress the role of the State of Rio de Janeiro as an important entrance point of dengue viruses in Brazil since the introduction of DEN-1 and DEN-2 viruses in 1986 and
1990, respectively, which resulted in a rapid spread of those virus all over the country (Nogueira et al. 1999).

\section{ACKNOWLEDGEMENTS}

To the field staff of the Sanitary District of Nova Iguaçu/ Vector Control Program for help in the mosquito collection and to Marcel Graça, José da Costa Farias Filho and José de Carvalho Filho for technical assistance.

\section{REFERENCES}

Braga IA, Galardo AKR, Garcia AC, Lima JB 2000. Evaluation of resistance of Aedes aegypti to temephos in Rio de Janeiro State, Brazil. J Am Mosq Contr Assoc 16: 298.

Chow VT, Chan YC, Yong R, Lee KM, Lim LK, Chung YK, Lam-Phua SG, Tan BT 1998. Monitoring of dengue viruses in field-caught Aedes aegypti and Aedes albopictus mosquitoes by a type-specific polymerase chain reaction and cycle sequencing. Am J Trop Med Hyg 58: 578-586.

Degallier N, da Rosa AP, Vasconcelos PF, Figueiredo LT, da Rosa JF, Rodrigues SG, da Rosa ES 1996. Dengue and its vectors in Brazil. Bull Soc Pathol Exot 89: 128-135.

Funasa-Fundação Nacional de Saúde 2001. Dengue. Situação epidemiológica, riscos e medidas de controle. Boletim Epidemiológico Eletrônico, http://www.funasa.gov.br

Gubler DJ, Clark GG 1996. Community involvement in the control of Aedes aegypti. Acta Trop 61: 169-179.

Gubler DJ, Kuno G, Sather GE, Velez M, Oliver A 1984. Mosquito cell cultures and specific monoclonal antbodies in surveillance for dengue viruses. Am J Trop Med Hyg 33: 158165.

Honório NA 1999. Estudos de Aspectos da Biologia do Aedes aegypti (Linnaeus, 1762) e Aedes albopictus (Skuse, 1894), em Area Endêmica de Dengue, no Estado do Rio de Janeiro, MSc Thesis, Instituto Oswaldo Cruz, Rio de Janeiro, 83 pp.

Honório NA, Lourenço-de-Oliveira R 2001. Freqüência de larvas e pupas de Aedes aegypti e Aedes albopictus em armadilhas, Brasil. Rev Saúde Púb 34: 385-391.

Igarashi A 1978. Isolation of a Singh's Aedes albopictus cell clone sensitive to dengue and chikungunya viruses. J Gen Virol 40: 531-544.

Kow CY, Koon LL, Yin PF 2001. Detection of dengue viruses in field caught male Aedes aegypti and Aedes albopictus (Diptera: Culicidae) in Singapore by type-specific PCR. $J$ Med Entomol 38: 475-479.

Lanciotti RS, Calisher CH, Gubler DJ, Chang GJ, Vorndam V 1992. Rapid detection and typing of dengue viruses from clinical samples by using reverse transcriptase-polimerase chain reaction. J Clin Microbiol 30: 545-551.

Miagostovich MP, Nogueira RMR, Cavalcanti SMB, Marzochi KBF, Schatzmayr HG 1993. Dengue epidemic in the State of Rio de Janeiro, Brazil: virological and epidemiological aspects. Rev Inst Med Trop São Paulo 35: 149-154.

Nogueira RMR, Miagostovich MP, Filippis AMB, Pereira MAS, Schatzmayr HG 2001. Dengue virus type 3 in Rio de Janeiro, Brazil. Mem Inst Oswaldo Cruz 96: 925-926.

Nogueira RMR, Miagostovich MP, Schatzmayr HG, Santos FB, Araujo ESM, Souza RV, Zagne SMO, Nicolai C, Baran M, Filho GT 1999. Dengue in the State of Rio de Janeiro, Brazil, 1986-1998. Mem Inst Oswaldo Cruz 94: 297-304.

Nogueira RMR, Schatzmayr HG, Miagostovich MP, Farias MFDB, Farias Filho JC 1988. Virological study of dengue type 1 epidemic at Rio de Janeiro, Brazil. Mem Inst Oswaldo Cruz 83: 219-225.

Rocco IM, Kavakama BB, Santos CLS 2001. First isolation of dengue 3 in Brazil from an imported case. Rev Inst Med Trop S Paulo 43: 55-57.

Schatzmayr HG, Nogueira RMR, Travassos da Rosa APA 1986. An outbreak of dengue virus at Rio de Janeiro. Mem Inst Oswaldo Cruz 81: 245-246. 